\title{
Performa Puyuh (Coturnix coturnix japonica) yang Disuplementasi Susu Bubuk Kadaluarsa pada Tingkat Protein Berbeda
}

\section{Performance of Quail (Coturnix coturnix japonica) Supplemented with Expired Powder Milk at Different Protein Levels}

\author{
R. Amizar ${ }^{1 *}$, H. I. H. O. Rambe' , G. Ciptaan'2, dan A. Djulardi ${ }^{2}$ \\ 'Program Studi Peternakan, Fakultas Peternakan, Universitas Andalas, Kampus II Payakumbuh - Indonesia \\ ${ }^{2}$ Program Studi Peternakan, Fakultas Peternakan, Universitas Andalas, Padang - Indonesia \\ *Corresponding E-mail: robiamzr@ansci.unand.ac.id \\ (Diterima: 24 Desember 2020; Disetujui: 27 April 2021)
}

\begin{abstract}
ABSTRAK
Penelitian bertujuan untuk mengetahui performa puyuh (Coturnix coturnix japonica) yang suplementasi susu bubuk kadaluarsa pada tingkat protein berbeda terhadap performa puyuh. Puyuh yang digunakan yaitu puyuh betina petelur (Coturnix coturnix japonica) periode pertumbuhan umur 21 hari sebanyak 240 ekor. Penelitian menggunakan metode Rancangan Acak Lengkap (RAL) pola faktorial $2 \times 3$ dengan 4 ulangan, setiap ulangan terdiri dari 10 ekor puyuh petelur. Penelitian terdiri dari dua faktor yaitu level kebutuhan protein (20\% dan 18\%) sebagai faktor pertama dan suplementasi susu bubuk kadaluarsa $(0 \% ; 0,25 \% ; 0,50 \%)$ sebagai faktor kedua. Peubah yang diamati yaitu konsumsi ransum (g/ ekor/hari), pertambahan bobot badan (g/ekor/hari), konversi ransum, dan umur pertama bertelur. Data yang diperoleh dianalisis dengan ANOVA, jika berbeda nyata diuji lanjut dengan DMRT. Hasil anasisis ragam menunjukkan bahwa suplementasi susu bubuk kadaluarsa dalam ransum berpengaruh tidak nyata $(\mathrm{P}>0,05)$ terhadap konsumsi ransum, pertambahan bobot badan, konversi ransum, dan umur pertama bertelur. Dapat disimpulkan bahwa pada level protein $18 \%$ dengan penambahan susu bubuk kadaluarsa sebanyak $0,50 \%$ dalam ransum puyuh periode pertumbuhan mampu mempertahankan performa puyuh dengan nilai konsumsi ransum 12,64 g/ekor/hari, pertambahan bobot badan 2,65 g/ekor/hari, konversi ransum 5,23, dan umur pertama bertelur 48 hari.
\end{abstract}

Kata kunci: performa puyuh, susu bubuk kadaluarsa, tingkat protein

\section{ABSTRACT}

This study aims to determine the performance of quail (Coturnix coturnix japonica) supplemented with expired milk powder at different protein levels on the performance of the quail growth period. The quail used were 240 laying female quail (Coturnix coturnix japonica) with a growth period of 21 days. The study used a completely randomized design (CRD) with a $2 \times 3$ factorial pattern with four replications; each replication consisted of 10 laying quails. The study consisted of two factors, namely the level of protein requirement (20\% and $18 \%)$ as the first factor and supplementation of expired milk powder $(0 \%$; $0.25 \% ; 0.50 \%)$ as the second factor. The observed variables were ration consumption (g/head/day), body weight gain (g/head/day), ration conversion, and age at first laying eggs. The data obtained were analyzed by ANOVA, if significantly different, further tested with DMRT. The analysis of variance showed that supplementation of expired milk powder in the ration had no significant effect $(P>0.05)$ on ration consumption, body weight gain, ration conversion, and age at first laying eggs. It can be concluded that the addition of expired milk powder as much as $0.50 \%$ at a protein level of $18 \%$ in the ration of quail during the growth period was able to maintain quail performance with a ration consumption value of $12.64 \mathrm{~g} / \mathrm{head} /$ day, body weight gain of $2.65 \mathrm{~g} / \mathrm{head} /$ day, ration conversion was 5.23. The first egg-laying age was 48 days.

Keywords: quail performance, expired milk powder, protein level 


\section{PENDAHULUAN}

Pakan atau ransum yang baik diberikan pada ternak yaitu mampu dicerna dan tidak mengganggu kesehatan ternak. Komponen pakan biasanya menjadi biaya yang paling besar dikeluarkan peternak puyuh yaitu berkisar 70-80\% dari seluruh biaya produksi (Kantra, 2016). Menurut Rasyaf (1997) ransum adalah campuran bahan-bahan pakan yang bertujuan untuk memenuhi kebutuhan zat-zat makanan yang seimbang dan tepat bagi ternak. Kebutuhan akan zat-zat makanan terutama pada kandungan protein, lemak, karbohidrat, vitamin, dan mineral. Terutama pada priode pertumbuhan, kebutuhan akan protein menjadi perhatian utama dalam pemeliharaan puyuh.

Kebutuhan protein sebagai upaya dalam pemenuhan asam amino pada ternak unggas didasarkan pada kadar protein kasar ransum. Protein kasar tidak diperlukan secara langsung untuk perindividu oleh ternak melainkan memerlukan asam amino dalam jumlah dan keseimbangan yang tepat (Widodo, 2002). Beberapa asam amino sulit dilengkapi dalam jumlah seimbang pada ternak unggas seperti metionin, lysin dan triptopan. Asam amino tersebut dinamakan asam amino esensial yang didalam tubuh tidak dapat disintesa sehingga menjadi perhatian saat menyusun ransum (Anggorodi, 1985). Kebutuhan protein menjadi perhatian utama karena harga pakan semakin mahal apalagi dari bahan pakan sumber protein yang diimpor seperti tepung ikan dan bungkil kedelai. Oleh sebab itu perlu dilakukan penurunan level penggunaan protein tanpa mengurangi performa dari ternak dengan memanfaatkan bahan pakan lokal sumber protein hasil limbah industri seperti susu bubuk kadaluarsa yang mengandung protein tinggi dan masih kaya akan asam amino esensial.

Susu bubuk kadaluarsa memiliki kandungan gizi yang masih baik digunakan untuk ternak puyuh. Susu bubuk kadaluarsa mengandung protein kasar 16,59\% (Laboratorium bioteknologi Ternak, 2020), lemak kasar 4,55\%, serat kasar 0,53\% (Laboratorium Teknologi Industri Pakan, 2019). Kalsium $0,426 \%$, fosfor $0,852 \%$ dan energi sebanyak $4022 \mathrm{kkal} / \mathrm{kg}$ (Laboratorium Nutrisi Non Ruminansia, 2019). Methionin $1,02 \%$, lysine $1,27 \%$ dan tripthopan $0,12 \%$ (Laboratorium Jasa Pengujian, Kalibrasi dan Sertifikasi, 2019). Susu bubuk kadaluarsa yang digunakan berupa makanan pendamping ASI yang disajikan dalam bentuk susu bubuk formula yang diberikan kepada bayi dan sudah melewati masa berlaku untuk dikonsumsi secara baik. Selama ini susu bubuk kadaluarsa akan langsung di bakar dan tidak dimanfaatkan lagi (Nestle, 2019).

Susu bubuk kadaluarsa merupakan salah satu sumber protein yang tidak termanfaatkan. Beberapa penelitian terdahulu telah pernah memanfaatkan susu bubuk kadaluarsa ini pada berbagai ternak. Menurut Warsito et al. (2012) susu afkir dapat diberikan sebanyak 5\% pada ayam broiler jantan. Pertiwi et al. (2017) menyatakan bahwa susu afkir mampu menggantikan $75 \%$ tepung ikan dalam ransum ayam buras. Sedangkan menurut Habibi et al. (2017) pemberian 7.5\% tidak berpengaruh pada ayam petelur. Sukma (2019) pemberian 5\% susu bubuk kadaluarsa memberikan pengaruh nyata pada performa ayam kampung. Namun pada puyuh, belum ditemukan informasi penggunaan susu bubuk kadaluarsa ini. Oleh sebab itu, maka disuplementasi kedalam ransum untuk melihat performa puyuh (Coturnix coturnix japonica) pada tingkat protein berbeda.

\section{METODE}

Penelitian ini dilakukan di kandang unggas Laboratorium percobaan, Laboratorium Non Ruminansia, Laboratorium Tekonologi Industri Pakan dan Laboratorium Bioteknologi Ternak Fakultas Peternakan Universitas Andalas dan Laboratorium Jasa Pengujian, Kalibrasi dan Sertifikasi Institut Pertanian Bogor. Penelitian dilaksanakan pada tanggal 28 Februari sampai tanggal 1 April 2020. Pada penelitian ini menggunakan 
Tabel 1. Kandungan nutrisi bahan pakan penyusun ransum

\begin{tabular}{lcccccccc}
\hline \multirow{3}{*}{ Sampel } & \multicolumn{7}{c}{ Hasil analisa didasarkan pada persentase berat kering } \\
\cline { 2 - 9 } & $\begin{array}{c}\text { PK } \\
(\%)\end{array}$ & $\begin{array}{c}\text { LK } \\
(\%)\end{array}$ & $\begin{array}{c}\text { SK } \\
(\%)\end{array}$ & $\begin{array}{c}\text { Met } \\
(\%)\end{array}$ & $\begin{array}{c}\text { Lys } \\
(\%)\end{array}$ & $\begin{array}{c}\text { Ca } \\
(\%)\end{array}$ & $\begin{array}{c}\text { P } \\
(\%)\end{array}$ & $\begin{array}{c}\text { EM } \\
(\mathrm{kkal} / \mathrm{kg})\end{array}$ \\
\hline $\begin{array}{l}\text { Susu bubuk } \\
\text { kadaluarsa }\end{array}$ & $16,59^{\mathrm{e}}$ & $4,55^{\mathrm{a}}$ & $0,53^{\mathrm{a}}$ & $3,25^{\mathrm{d}}$ & $1,7^{\mathrm{d}}$ & $0,42^{\mathrm{c}}$ & $0,85^{\mathrm{c}}$ & $4022^{\mathrm{c}}$ \\
Dedak & $10,14^{\mathrm{a}}$ & $6,72^{\mathrm{a}}$ & $11,51^{\mathrm{a}}$ & $0,27^{*}$ & $0,67^{*}$ & $0,37^{\mathrm{c}}$ & $0,84^{\mathrm{c}}$ & $1640^{* *}$ \\
Jagung & $9,28^{\mathrm{a}}$ & $2,44^{\mathrm{a}}$ & $2,03^{\mathrm{a}}$ & $0,18^{*}$ & $0,26^{*}$ & $0,21^{\mathrm{c}}$ & $0,17^{\mathrm{c}}$ & $3300^{* *}$ \\
Konsentrat & $37,23^{\mathrm{e}}$ & $3,40^{\mathrm{a}}$ & $8,00^{\mathrm{f}}$ & $1,02^{\mathrm{d}}$ & $1,27^{\mathrm{d}}$ & $5,50^{\mathrm{f}}$ & $1,00^{\mathrm{f}}$ & $2753^{\mathrm{c}}$ \\
Tepung Tulang ${ }^{\mathrm{b}}$ & 0 & 0 & 0 & 0 & 0 & 24 & 12 & 0 \\
\hline
\end{tabular}

Keterangan: a = Laboratorium Teknologi Industri Pakan (2019), b= Nuraini et al. (2018), c = Laboratorium Nutrisi Non Ruminansia (2019), d = Laboratorium Jasa Pengujian, Kalibrasi dan Sertifikasi (2019), e = Laboratorium Bioteknologi Ternak (2020), f= Label Kemasan Produk PT. Charoen Pokphan, * = Nuraini et al. (2019), ** = Scot et al. (1982)

Tabel 2. Komposisi ransum perlakuan

\begin{tabular}{lcccccc}
\hline \multirow{2}{*}{ Bahan pakan } & \multicolumn{7}{c}{ Ransum Perlakuan (\%) } \\
\cline { 2 - 7 } & R1S1 & R1S2 & R1S3 & R2S1 & R2S2 & R2S3 \\
\hline Dedak Halus & 7,50 & 7,50 & 7,50 & 9,50 & 9,50 & 9,50 \\
Jagung halus & 49,50 & 49,50 & 49,50 & 53,50 & 53,50 & 53,50 \\
Konsentrat 126 & 39,50 & 39,50 & 39,50 & 33,50 & 33,50 & 33,50 \\
Tepung tulang & 3,50 & 3,50 & 3,50 & 3,50 & 3,50 & 3,50 \\
Susu bubuk kadaluarsa* & 0 & 0,25 & 0,50 & 0 & 0,25 & 0,50 \\
\hline Total & 100 & 100,25 & 100,5 & 100 & 100,25 & 100,5 \\
\hline
\end{tabular}

Keterangan: * = Sebagai suplemen ditambahkan di luar 100\% ransum

Tabel 3. Kandungan nutrisi ransum perlakuan

\begin{tabular}{lcccccc}
\hline Kandungan & \multicolumn{7}{c}{ Ransum Perlakuan (\%) } \\
\cline { 2 - 7 } Nutrisi & R1S1 & R1S2 & R1S3 & R2S1 & R2S2 & R2S3 \\
\hline EM & 2843,94 & 2853,99 & 2864,05 & 2843,56 & 2853,61 & 2863,67 \\
PK & 20,06 & 20,10 & 20,14 & 18,40 & 18,44 & 18,48 \\
LK & 3,05 & 3,07 & 3,08 & 3,08 & 3,09 & 3,11 \\
Sk & 5.03 & 5,03 & 5,03 & 4,86 & 4,86 & 4,86 \\
Ca & 3,14 & 3,15 & 3,15 & 2,83 & 2,83 & 2,83 \\
P & 1,24 & 1,25 & 1,25 & 1,22 & 1,22 & 1,22 \\
Met & 0,51 & 0,52 & 0,53 & 0,46 & 0,47 & 0,48 \\
Lys & 0.68 & 0,68 & 0,69 & 0,63 & 0,63 & 0,64 \\
\hline Total & 100 & 100 & 100 & 100 & 100 & 100 \\
\hline
\end{tabular}

Keterangan: Dihitung berdasarkan Tabel 1 dan Tabel 2.

$\mathrm{R} 1 \mathrm{~S} 1=$ tingkat protein $(20 \%)$ dan tanpa suplementasi susu bubuk $(0 \%), \mathrm{R} 1 \mathrm{~S} 2=$ tingkat protein $(20 \%)$ dan suplementasi susu bubuk $(0,25 \%), \mathrm{R} 1 \mathrm{~S} 3$ = tingkat protein $(20 \%)$ dan suplementasi susu bubuk (0,50\%), R2S1 = tingkat protein (18\%) dan tanpa suplementasi susu bubuk (0\%), $\mathrm{R} 2 \mathrm{~S} 2=$ tingkat protein $(18 \%)$ dan suplementasi susu bubuk $(0,25 \%), \mathrm{R} 2 \mathrm{~S} 3=$ tingkat protein $(18 \%)$ dan suplementasi susu bubuk $(0,50 \%)$ 
puyuh petelur (Coturnix coturnix japonica) umur 21 hari ( 3 minggu) yang berada pada fase grower/pertumbuhan sebanyak 240 ekor. Kandang yang digunakan jenis baterai yang

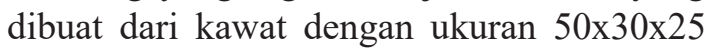
$\mathrm{cm}$ sebanyak 24 unit yang ditempati sebanyak 10 ekor puyuh per unit. Kandang dilengkapi tempat pakan dan tempat minum yang ditempatkan pada setiap unitnya. Untuk penerangan dan pemanas digunakan lampu pijar 40 Watt dua buah. Kemudian alat yang digunakan untuk menimbang ransum adalah timbangan digital.

\section{Ransum Percobaan}

Bahan pakan penyusun ransum yaitu jagung halus, dedak halus, konsentrat 126, tepung tulang. Susu bubuk kadaluarsa sebagai perlakuan diberikan dalam bentuk suplementasi. Ransum disusun menurut Djulardi (1995) yaitu dengan dengan protein $20 \%$ dan $18 \%$ dengan energi $2800 \mathrm{kkal} /$ $\mathrm{kg}$. Ransum dan air minum diberikan secara adlibitum.

\section{Rancangan Penelitian}

Penelitian menggunakan Rancangan Acak Lengkap (RAL) pola faktorial $2 \times 3$ dengan 4 ulangan. Data yang diperoleh diolah menggunakan statistik dengan analisis varian (ANOVA dengan uji $\mathrm{F}$ pada taraf signifikansi $5 \%$. Jika berpengaruh nyata $(\mathrm{P}>0,05)$ dari hasil analisis ragam, maka dilanjutkan dengan uji DMRT (Steel dan Torrie, 1995). Perlakuan penelitian yaitu faktor pertama level pemberian kebutuhan protein yaitu R1: Pemberian kebutuhan protein $(20 \%)$, R2: Pemberian kebutuhan protein (18\%). Sedangkan faktor kedua terdiri dari 3 level suplementasi susu bubuk kadaluarsa yaitu S1: Tanpa suplementasi susu bubuk kadaluarsa $(0 \%), \quad$ S2: Suplementasi susu bubuk kadaluarsa $(0,25 \%)$, S3: Suplementasi susu bubuk kadaluarsa $(0,50 \%)$.

\section{Peubah yang Diamati}

Peubah yang diamati performa dari puyuh yaitu kosnumsi ransum, pertambahan bobot badan, konversi ransum, dan umur pertama bertelur yang dihitung menggunakan rumus berikut:

\section{A. Konsumsi Ransum}

Konsumsi ransum dihitung dengan cara menimbang ransum yang diberikan setiap minggu kepada puyuh dan dikurangi ransum sisa pada akhir minggu sebelumnya (g/ekor/hari).

Konsumsi $\operatorname{ransum}(\mathrm{g} / \mathrm{ekor} / \mathrm{hari})=$ ransum yang diberikan $(\mathrm{g})$ - ransum sisa $(\mathrm{g})$

\section{B. Pertambahan Bobot Badan}

Data pertambahan bobot badan diperoleh dengan cara penimbangan setiap minggu yang merupakan selisih antara penimbangan bobot badan akhir dengan penimbangan bobot badan awal per satuan waktu (g/ekor/hari).

Pertambahan bobot badan $(\mathrm{g} / \mathrm{ekor} / \mathrm{hari})=$

$\underline{\text { bobotbadan akhir (g)- bobot badan awal (g) }}$

$$
7 \text { hari }
$$

\section{Konversi Ransum}

Konversi ransum adalah perbandingan jumlah ransum yang dikonsumsi pada satu minggu dengan pertambahan bobot badan pada minggu itu.

Konversiransum $=\frac{\text { konsumsi ransum }(\mathrm{g})}{\text { pertambahan bobot badan }(\mathrm{g})}$

\section{Umur Pertama Bertelur}

Umur pertama bertelur dihitung dengan cara mencatat saat pertama kali puyuh bertelur.

\section{HASIL DAN PEMBAHASAN}

\section{Konsumsi Ransum}

Berdasarkan hasil penelitian didapatkan rataan konsumsi ransum puyuh umur 3-5 minggu berkisar antara 12,64-12,67 g/ekor/hari (Tabel 4). Dari hasil penelitian ini menunjukkan bahwa suplementasi susu bubuk kadaluarsa pada tingkat protein yang berbeda dalam ransum berpengaruh berbeda tidak nyata $(\mathrm{P}>0,05)$ terhadap konsumsi ransum puyuh. Nilai rataan konsumsi ransum 
JPI Vol. 23 (2): 208-217

Tabel 4. Konsumsi Ransum (g/ekor/hari)

\begin{tabular}{lccc}
\hline \multirow{2}{*}{ Jumlah Suplementasi } & \multicolumn{2}{c}{ Protein Ransum } & \multirow{2}{*}{ Rata-rata } \\
\cline { 2 - 3 } & R1 $(20 \%)$ & R2 $(18 \%)$ & 12,65 \\
S1 $(0 \%)$ & 12,64 & 12,67 & 12,65 \\
S2 $(0,25 \%)$ & 12,66 & 12,65 & 12,64 \\
S3 $(0,50 \%)$ & 12,65 & 12,64 & 12,65 \\
\hline Rata-rata & 12,65 & 12,65 & \\
\hline
\end{tabular}

Keterangan: $(\mathrm{P}>0,05)$

Tabel 5. Pertambahan Bobot Badan (g/ekor/hari)

\begin{tabular}{lccc}
\hline \multirow{2}{*}{ Jumlah Suplementasi } & \multicolumn{2}{c}{ Protein Ransum } & \multirow{2}{*}{ Rata-rata } \\
\cline { 2 - 3 } & R1 $(20 \%)$ & R2 $(18 \%)$ & 2,56 \\
S1 $(0 \%)$ & 2,66 & 2,46 & 2,70 \\
S2 $(0,25 \%)$ & 2,63 & 2,77 & 2,64 \\
S3 $(0,50 \%)$ & 2,64 & 2,65 & 2,63 \\
\hline Rata-rata & 2,64 & 2,62 & \\
\hline
\end{tabular}

Keterangan: $(\mathrm{P}>0,05)$

tersebut masih dalam batas konsumsi standar pada puyuh periode pertumbuhan. Menurut Djulardi (1995) konsumsi ransum puyuh pada umur 21-41 hari yaitu sebesar 10-15 g/ekor/ hari. Abidin (2002) menyatakan konsumsi ransum puyuh pada umur 21-40 hari yaitu sebesar 8-15 g/ekor/hari. Ditambahkan oleh Srigharet (2002) konsumsi ransum puyuh umur 3-6 minggu yaitu 8-15 g/ekor/hari.

Peningkatan level suplementasi susu bubuk kadaluarsa sampai $0.50 \%$ dengan penurunan tingkat protein menjadi $18 \%$ belum menunjukkan perbedaan terhadap konsumsi ransum. Tidak adanya interaksi antara level protein dan supelementasi susu bubuk kadaluarsa disebabkan karena ransum masih palatable oleh puyuh dan pada protein ransum 18\% masih memenuhi kebutuhan sehingga tidak mempengaruhi konsumsi ransum puyuh. Seperti yang dinyatakan oleh Kartadisastra (1997) bahwa palatabilitas diberikan dari sifat performa dari bahan-bahan akibat dari bentuk fisik dan sifat kimiawi dari bahan pakan tersebut. Menurut Irawan et al. (2012) puyuh pada dasarnya akan mengkonsumsi ransum untuk memenuhi energinya. Hal ini senada dengan yang dinyatakan oleh Wahju (2004) bahwa jika puyuh akan mengkonsumsi pakan sampai energinya terpenuhi.

Susu bubuk kadaluarsa memberikan bau dan rasa spesifik pada ransum yang memungkinkan disukai oleh puyuh. Selain itu, warna ransum juga cerah sehingga menjaga konsumsi ransum puyuh, selain itu komposisi jagung dalam ransum pada perlakuan tidak jauh berbeda. Menurut Setiawan (2006) tingkat konsumsi pakan puyuh salah satunya dipengaruhi oleh tingkat palatabilitas pakan. Ditambahkan oleh Mahata et al. (2008) bahwa konsumsi ransum dapat dipengaruhi oleh warna, rasa dan aroma atau bau pakan.

\section{Pertambahan Bobot Badan}

Hasil analisis ragam menunjukkan bahwa suplementasi susu bubuk kadaluarsa pada tingkat protein yang berbeda dalam ransum berpengaruh berbeda tidak nyata $(\mathrm{P}>0,05)$ terhadap pertambahan bobot badan puyuh petelur (Tabel 5). Hal ini sejalan dengan tidak adanya pengaruh perbedaan pada konsumsi ransum puyuh. Tidak adanya interaksi antara level protein dan supelementasi susu bubuk kadaluarsa disebabkan karena jumlah zat-zat makanan terutama asam amino masih seimbang didalam ransum yang diperlukan untuk pertumbuhan. Hal ini 
JPI Vol. 23 (2): 208-217

Tabel 6. Konversi Ransum

\begin{tabular}{lccc}
\hline \multirow{2}{*}{ Jumlah Suplementasi } & \multicolumn{2}{c}{ Protein Ransum } & \multirow{2}{*}{ Rata-rata } \\
\cline { 2 - 3 } & R1 $(20 \%)$ & R2 $(18 \%)$ & \\
\hline S1 $(0 \%)$ & 5,04 & 5,51 & 5,27 \\
S2 $(0,25 \%)$ & 5,20 & 5,11 & 5,15 \\
S3 $(0,50 \%)$ & 5,07 & 5,23 & 5,15 \\
\hline Rata-rata & 5,10 & 5,28 & 5,19 \\
\hline
\end{tabular}

Keterangan: $(\mathrm{P}>0,05)$

mengakibatkan pertambahan bobot bahan juga tidak berpengaruh nyata. Umur puyuh yang menjelang dewasa akan mengakibatkan penurunan pertambahan bobot badan. Hal ini dikarenakan respon pertumbuhan tidak sebesar sebelumnya karena penggunaan zat makanan terutama protein lebih diarahkan pada perkembangan reproduksi untuk proses produksi telur.

Persentase pertambahan bobot badan pada puyuh umur 3-5 minggu dengan suplementasi susu bubuk kadaluarsa pada tingkat protein yang berbeda berkisar antara 2,46-2,77 g/ekor/hari (Tabel 5). Hasil rataan pertambahan bobot badan tersebut masih dalam batas normal. Menurut Saleh et al. (2005) memperoleh pertambahan bobot badan puyuh umur 3-6 minggu sebesar 2,32-2,92 g/ekor/hari. Asiyah et al. (2013) menyatakan pertambahan bobot badan puyuh umur 3-6 minggu yaitu 2,77-3,28 g/ekor/ hari. Selain itu, pada level protein $20 \%$ dan $18 \%$ dan pemberian susu bubuk kadaluarsa sampai $0,50 \%$ masih menyediakan kebutuhan asama amino esensial bagi ternak puyuh seperti metionin, lysin, dan tryptophan. Asam-asam amino esensial ini berguna bagi pertumbuhan, metabolisme, sintesis protein, imunitas, meningkatkan performa ternak (Prawirokusumo et al., 1987; Metzler-Zebeli et al., 2009; Sundari et al., 2004).

Rataan pertambahan bobot badan pada perlakuan R2S2 yaitu 2,77 g/ ekor/hari, menunjukkan bahwa dengan suplementasi susu bubuk kadaluarsa sebanyak $(0,25 \%)$ pada tingkat protein $18 \%$ dapat meningkatkan pertambahan bobot badan, menunjukkan bahwa asam amino dan zat makanan yang terkandung dalam susu bubuk kadaluarsa dengan protein (18\%) masih dapat meningkatkan bobot badan. Sebaliknya rataan pertambahan bobot badan pada perlakuan R2S1 yaitu 2,46 g/ekor/hari, menunjukkan bahwa tanpa suplementasi susu bubuk kadaluarsa $(0 \%)$ dengan protein $(18 \%)$ dapat menghambat pertambahan bobot badan. Hal ini dikarenakan tidak adanya penambahan asam amino serta zat makanan dari susu bubuk kadaluarsa dan rendahnya protein yang terkandung dalam ransum. Menurut Card and Nesheim (1972) menyatakan bahwa kandungan protein dan asam amino yang seimbang akan meningkatkan pertambahan bobot badan ternak. Rasyaf (2003) mengemukakan bahwa pertambahan bobot badan dipengaruhi oleh kualitas dan kuantitas pakan yang dikonsumsi.

\section{Konversi Ransum}

Hasil analisis ragam menunjukkan bahwa suplementasi susu bubuk kadaluarsa pada tingkat protein yang berbeda dalam ransum berpengaruh berbeda tidak nyata $(\mathrm{P}>0,05)$ terhadap konversi ransum puyuh petelur (Tabel 6). Hal ini sejalan dengan tidak adanya pengaruh perbedaan pada konsumsi ransum dan pertambahan bobot badan. Konversi ransum merupakan perbandingan ransum yang dikonsumsi ternak puyuh untuk menghasilkan pertambahan bobot badan, apabila suplementasi susu bubuk kadaluarsa pada tingkat protein yang berbeda pada ransum tidak mempengaruhi konsumsi ransum dan pertambahan bobot badan, maka konversi ransum yang dihasilkan juga tidak berpengaruh.

Tidak adanya interaksi antara level 
Tabel 7. Umur Pertama Bertelur (hari)

\begin{tabular}{lccc}
\hline \multirow{2}{*}{ Jumlah Suplementasi } & \multicolumn{2}{c}{ Protein Ransum } & \multirow{2}{*}{ Rata-rata } \\
\cline { 2 - 3 } & R1 $(20 \%)$ & R2 $(18 \%)$ & 48,00 \\
S1 $(0 \%)$ & 48,00 & 48,00 & 51,00 \\
S2 $(0,25 \%)$ & 51,00 & 51,00 & 49,00 \\
S3 $(0,50 \%)$ & 50,00 & 48,00 & 49,21 \\
\hline Rata-rata & 49,50 & 48,92 & \\
\hline
\end{tabular}

Keterangan: $(\mathrm{P}>0,05)$

protein dan supelementasi susu bubuk kadaluarsa terhadap konversi ransum disebabkan karena seimbangnya kualitas zat-zat makanan terutama asam amino dalam ransum dan pertambahan bobot badan yang relatif sama disetiap pelakuan. Yatno (2009) menyatakan bahwa konversi ransum erat kaitannya dengan konsumsi ransum dan pertambahan bobot badan. Anggorodi (1995) menyatakan bahwa kualitas ransum sangat menentukan besar kecilnya konversi yang dihasilkan, ransum yang bermutu baik dengan kandungan gizi yang seimbang dan mempunyai palatabilitas tinggi menjadi konversi ransum yang dihasilkan semakin baik, sebaliknya ransum yang bermutu rendah dengan palatabilitas rendah menghasilkan konversi yang rendah.

Persentase konversi ransum pada puyuh umur 3-5 minggu dengan suplementasi susu bubuk kadaluarsa pada tingkat protein yang berbeda berkisar antara 5,04-5,23 (Tabel 6). Konversi ransum pada penelitian ini lebih tinggi dibandingkan dengan Kaharuddin (2007) yang menyatakan bahwa nilai konversi ransum puyuh periode pertumbuhan yaitu $3,91-4,17$. Konversi ransum puyuh periode pertumbuhan yang ideal yaitu 3,67-4,71 (Hazim et al., 2010). Tingginya nilai konversi ransum dalam penelitian ini disebabkan pemanfaatan ransum oleh puyuh tidak hanya untuk menghasilkan pertambahan bobot badan tetapi juga mulai digunakan untuk produksi telur. Seperti yang diketahui bahwa puyuh yang digunakan yaitu puyuh periode pertumbuhan yang memasuki periode bertelur. Sehingga ransum tidak sepenuhnya digunakan untuk pertambahan bobot badan namun mulai bergeser untuk memenuhi kebutuhan nutrisi untuk produksi telur. Seperti yang dinyakan oleh yang dinyatakan oleh Wahju (2004) bahwa jika puyuh akan mengkonsumsi pakan sampai energinya terpenuhi. Yunilas et al. (2008) menambahkan angka konversi ransum dapat menunjukkan tingkat efisiensi penggunaan ransum, semakin besar angka konversi ransum maka penggunaan ransum kurang efisien.

\section{Umur Pertama Bertelur}

Hasil analisis ragam menunjukkan bahwa suplementasi susu bubuk kadaluarsa pada tingkat protein yang berbeda dalam ransum berpengaruh berbeda tidak nyata $(\mathrm{P}>0,05)$ terhadap umur pertama bertelur puyuh petelur (Tabel 7). Hal ini sejalan dengan tidak adanya pengaruh perbedaan pada konsumsi ransum puyuh. Jumlah zatzat makanan dengan kualitas yang sama dalam ransum mengakibatkan perkembangan saluran reproduksi puyuh sudah berkembang sehingga umur bertelur puyuh juga relatif sama. Scott et al. (1982) menyatakan bahwa kualitas dari protein sangat berperan dalam menentukan produksi telur.

Persentase umur pertama bertelur pada puyuh dengan suplementasi susu bubuk kadaluarsa pada tingkat protein yang berbeda berkisar antara 49,21 hari (Tabel 7). Umur pertama bertelur pada penelitian ini lebih lambat dibandingkan dengan Yatno (2009) yang melaporkan bahwa umur pertama bertelur pada puyuh yaitu 46 hari. Masroh et al. (2014) menyatakan umur pertama bertelur pada puyuh yaitu 47 hari. Mufti (1997) menyatakan bahwa burung puyuh mulai bertelur pada umur 6 minggu (42 
hari). Ditambahkan oleh Listiyowati dan Roospitasari (2009) puyuh mampu mencapai dewasa kelamin pada umur 42 hari dan sudah menghasilkan telur. Lambatnya umur pertama bertelur pada penelitian ini dipengaruhi oleh genetik dan ransum yang dikonsumsi oleh puyuh. Menurut Zainuddin dan Syahruddin (2012) lambatnya umur induk bertelur berkaitan dengan genetik dari puyuh yang dipelihara.ditambahkan oleh Wiradimaja et al. (2007) menyatakan bahwa faktor yang mempengaruhi umur bertelur pertama salah satunya yaitu pengaruh manajemen, ransum, dan bobot badan.

\section{KESIMPULAN}

Berdasarkan hasil penelitian yang dilakukan dapat disimpulkan bahwa pada level protein $18 \%$ dengan penambahan susu bubuk kadaluarsa sebanyak $0,50 \%$ dalam ransum puyuh periode pertumbuhan mampu mempertahankan performa puyuh dengan nilai konsumsi ransum 12,64 g/ekor/hari, pertambahan bobot badan 2,65 g/ekor/hari, konversi ransum 5,23, dan umur pertama bertelur 48 hari.

\section{DAFTAR PUSTAKA}

Abidin, Z. 2002. Meningkatkan Produktivitas Puyuh. Agro Media Pustaka. Jakarta.

Anggorodi, H. R. 1985. Nutrisi Aneka Ternak Unggas. Penerbit PT. Gramedia, Jakarta.

Anggorodi, R. 1995. Kemajuan Mutakhir Dalam Ilmu Makanan Ternak Unggas Cetakan Pertama. UI Press Jakarta.

Asiyah, N., D. Sunarti, dan U. Atmomarsono. 2013. Performa Burung Puyuh(Coturnix coturnix japonica) Umur 3 sampai 6 Minggu dengan Pola Pemberian Pakan Bebas Pilih (Free choice Feeding). Animal Agricultural Journal, Vol 2(1): 497-502.

Nestle. 2019. Bagian Pemusnahan Nestle
Padang (unpublish).

Card, L. E. and M.C. Nesheim. 1972. Poultry Production 7th Ed. Lea and Febringer, Philadelphia.

Djulardi, A. 1995. Respon Burung Puyuh Petelur (Coturnix coturnix japonica) Terhadap Pemberian Ransum dengan Berbagai Kandungan Fosfor dan Imbangan Energi Protein. Disertasi Pasca Sarjana Universitas Padjajaran, Bandung.

Laboratorium Bioteknologi Ternak. 2020. Hasil Analisis Laboratorium. Fakultas Peternakan Universitas Andalas, Padang.

Laboratorium Jasa Pengujian, Kalibrasi dan Sertifikasi. 2019. Hasil Analisis Laboratorium. Institut Pertanian Bogor, Bogor.

Laboratorium Nutrisi Non Ruminansia. 2019. Hasil Analisis Laboratorium. Fakultas Peternakan Universitas Andalas, Padang.

Laboratorium Teknologi Industri Pakan. 2019. Hasil Analisis Laboratorium. Fakultas Peternakan Universitas Andalas, Padang.

Hazim, J. A., H. A. Al-Mashadani., W. K. Al-Hayani., H. A. Mirza, and A. S. Al- Hassani. 2010. Effect of Diety Supplementation With Different Oils On Productive and Reproductive Performance Of Quail. J Poultry. Sci 9(5). 429-435.

Kaharuddin, D. 2007. Performa Puyuh Hasil Pembibitan Perternakan Rakyat di Kota Bengkulu. Jurnal Ilmu-ilmu Pertanian Indonesia Edisi Khusus 3:396-400.

Kantra, I. 2016. Pengaruh Penambahan Tepung Limbah Udang Dalam Ransum Terhadap Performan Puyuh Petelur (Coturnix coturnix japonica). Fakultas Peternakan. Universitas Islam Negeri Sultan Syarif Kasim Riau, Pekanbaru.

Listiyowati, E. dan Roospitasari, K. 2009. Beternak Puyuh Secara Komersial. 
Penebar Swadaya, Jakarta.

Mahata, M. E., A. Dharman, I. Ryanto. and Y. Rizal. 2008. Effect of Substituting Shrimp Waste Hydrolysate of Penaeus merguensis for Fish Meal in Broiler Permormance. Pakistan Jurnal of Nutrition. 7(6): 806-810.

Masroh, F. K., E. Sudjarwo, dan E. Widodo. 2014. Pengaruh Penambahan Tepung Kulit Singkong Terfermentasi Terhadap Performa Pertumbuhan dan Umur Pertama Bertelur pada Puyuh. Laporan Penelitian. Fakultas Peternakan Universitas Brawijaya, Malang.

Mezler-Zebeli, B. U., Eklund, M., and Mosenthin, R. 2009. Impact of Osmoregulary and Methyl donor Functions of Betaine on Intestinal Health and Perfomance in Poultry. World's Poultry Science Journal. 65(3), 419-442.

Mufti, M. 1997. Dampak Fotoregulasi dan Tingkat protein Ransum Selama Periode Pertumbuhan Terhadap Kinerja Burung Puyuh Petelur. Tesis. Pascasarjana, Institut Pertanian Bogor, Bogor.

Nuraini., Y. S. Nur, dan A. Djulardi. 2018. Pod Kakao Fermentasi dengan Pleurotus ostreatus untuk Memproduksi Telur dan Daging Unggas yang Rendah Kolesterol. Laporan Penelitian Hikom DIKTI. LPPM Universitas Andalas, Padang.

Nuraini., A. Djulardi, dan D. Yuzaria. 2019. Limbah Sawit Fermentasi untuk unggas. Suka Bina Press. ISBN: 978623-7018-31-5.

Prawirokusumo, S., Nasrudin, dan Umiyeni.1987. Suplementasi

Methionin Pada Ransum Ayam Pedaging Berkadar Cassava Tinggi. Proceding Seminar.

Rasyaf, M. 1997. Penyajian Makanan Ayam Petelur. Penebar Swadaya. Jakarta.
Rasyaf, M. 2003. Bahan Makanan Unggas di Indonesia. Kanisius. Yogyakarta.

Saleh. E., M. T. Jacob, dan D. Prayitno. 2005. Pengaruh Pemberian Tepung Buah Tanjung (Mimisops elegy I.) Dalam Ransum Terhadap Performa Puyuh (Coturnix coturnix japonica). J Ilmiah Peternakan Kultura. 40 (1): 1-4

Scott, M. L., M. C. Nesheim, and R. J. Young. 1982. Nutrition of The Chicken Fourth Ed. Published by M. L. Scott and Associates, Ithaca. New York.

Setiawan, D. 2006. Performa Produksi Burung Puyuh pada Perbandingan Jantan dan Betina yang Berbeda. Fakultas Peternakan Institut Pertanian Bogor.

Srigharet, N. 2002. Effect of Heat Stress on Histological Features in Pituicytes and Hepatocytes, and Enzyme Activities of Liver and Blood Plasma in Japanese Quail (Coturnix coturnix japonica) Journal of Poultry Science. 39(2):167-178

Steel, C. J. dan J.H. Torrie.1995. Prinsip dan Prosedur Statistik. PT. Gramedia, Jakarta.

Sundari, L, C, M Srilestari, dan H. I. Wahyuni. 2004. Komposisi Lemak Tubuh Kelinci Yang Mendapat Pakan Pelet Dengan Berbagai Aras Lisin. Fakultas Peternakan Universitas Diponegoro, Semarang.

Widodo, W. 2002. Nutrisi Pakan Unggas Kontekstual. Fakultas PeternakanPerikanan Universitas Muhammadiyah, Malang.

Wiradimaja, R., W. G. Piliang, M. T. Suhartono, dan W. Manalu. 2007. Umur Dewasa Kelamin Puyuh Jepang Betina yang Diberi Tepung Daun Katuk (Sauropus androgynus). Animal Production. 9(2): 67-72.

Yatno. 2009. Isolasi Protein Bungkil Inti Sawitdan Kajian Nilai Biologisnya sebagai Alternatif Bungkil Kedelai Pada Puyuh. Disertasi. Sekolah 
Pascasarjana, Institut Pertanian Bogor, Bogor.

Yunilas, B. Irawati, dan D. P. K. Tubagus. 2008. Pemanfaatan Tepung Kulit Buah Terong Belanda (Cyphomandra Betacea) Fermentasi (Aspergillus Niger) Terhadap Produksi Telur puyuh. Jurnal Agribisnis Peternakan. 4 (1): 2030

Zainuddin dan Syahruddin. 2012. Pemanfaatan Tepung Keong Mas sebagai Substitusi Tepung Ikan dalam Ransum Terhadap Performa dan Produksi Telur Puyuh. Laporan Penelitian. Fakultas IlmuIlmu Pertanian Universitas Negeri Gorontalo, Gorontalo.

Pertiwi, M. E. D., I. M. Mastika, dan I. M. Nuriyasa. 2017. Pengaruh Penggantian Tepung Ikan Dengan Susu Afkir Dalam Ransum Terhadap Performa Produksi dan Kecernaan Nutrien Ayam Buras Jantan. Majalah Ilmiah Peternakan. 20(3): 123-128.

Sukma, Y. C. 2019. Pengaruh Penggunaan Susu Bubuk Kadaluarsa Dalam Pakan Terhadap Pertambahan Bobot Badan
Padaayam Kampung. Artikel Program Studi Peternakan Fakultas Peternakan Universitas Nusantara Pgri Kediri

Warsito, S. H., M. N. Alim., and Wurlina. 2012. Effect of Waste Milk on The Performance of Male Broiler. AGROVETERINER. 1(1): 17-23.

Habibi., Warnoto, dan S. Johan. 2017. Pengaruh Pemberian Susu Bubuk Afkir Terhadap Performans Pertumbuhan Ayampetelur Umur 6 - 14 Minggu. Undergraduated thesis, Universitas Bengkulu.

Kartadisastra, H.R. 1997. Penyediaan dan Pengelolahan Pakan Ternak Ruminansia. Kasinius. Yogyakarta.

Irawan, I., D. Sunarti dan L. D, Mahfudz. 2012. Pengaruh pemberian pakan bebas pilih terhadap kecernaan protein burung puyuh (coturnix-coturnix japanica). Animal Agriculture Journal. 1 (2) : 238-245.

Wahju, J. 2004. Ilmu Nutrisi Unggas. Gadjah Mada University Press. Yogyakarta. 